\title{
Aporias literárias: questões borgeanas na educação ${ }^{1}$
}

Literary aporias: borgean issues in education

Máximo Daniel Lamela Adói

Faculdade de Educação da UFRGS

\section{Resumo}

Este texto escolhe abordar certo universo da literatura borgeana a partir de três pontos desdobrados em temáticas da Educação. Trata-se de sinalizações que procuram indicar ao leitor uma ênfase nos modos de ler como precursores ativos de uma política da imaginação na Educação. Essa política faz da literatura um dispositivo que compõe, com o ato leitor, um estado de humor poético que arrasta os ímpetos classificatórios ao campo das potências do imaginário. Tal ênfase nos modos de ler procura ser evidenciada nos seguintes pontos: 1) A invenção de Borges (a subjetivação como um efeito de variação); 2) O conhecimento como fabulação (a erosão da verdade como essência) e 3) 0 anacronismo como procedimento didático (uma didática dos modos de ler).

Palavras-chave: Leitura, Literatura, Borges, Educação.

\section{Abstract}

This paper approaches a certain universe of the Borgean literature from three points unfolded in Education themes. They are signs attempting to point out to the reader an emphasis on the ways of reading as active precursors of an imagination police in Education. Such police converts literature into a device that composes, together with the reading act, a state of poetic humor that drags the classifying impetuses to the field of potencies of the imaginary. This emphasis on the ways of reading may be evidenced in the following aspects: 1) Borges' invention (the subjectivation as a variation effect), 2) Knowledge as fabulation (the erosion of truth as essence), and 3) Anachronism as a didactic procedure (a didactics of ways of reading).

Keywords: Reading, Literature, Borges, Education.

Pensar a educação e a literatura tem me ocupado com certo entusiasmo. A Teoria literária e a literatura são parceiras potenciais em questões presentes no cotidiano docente, tanto que não considero que sejam mundos apartados, a literatura de um lado e a educação de outro. No meu entendimento e prática, trata-se de pensamentos que se retroalimentam e nascem num mesmo mundo. Quero dizer que são modos de tratar o conhecimento como um estado de espírito que transforma nossos corpos e nosso modo de conceber a nós mesmos e à vida.

\section{Um mundo dualizado}

\footnotetext{
1 A primeira versão deste texto foi apresentada em 15 de abril de 2016 por meio de Comunicação Oral (Palestra) realizada a convite do Grupo de Estudos e Pesquisas em Arte, Educação e Cultura (GEPAEC) do Programa de Pós-graduação em Educação da Universidade Federal de Santa Maria - UFSM. Por esse motivo permanece no texto o tom e a diç̧ão da oralidade.
} 
Com relação ao pensamento voltado para o campo da educação e àquele que deriva e se constitui no campo concernente à literatura podemos afirmar que, se há entre eles alguma separação esta tomou corpo nos anseios em instrumentalizar o conhecimento em campos de saberes. Corpo que ganhou forma quando estes anseios quiseram desenvolver um saber sistemático e secular a respeito da realidade, um saber que de algum modo fosse empiricamente validado, universalizado, verificado (WALLERSTEIN, 1996, p. 14).

Vemos essa instrumentalização tomar forma de modo cambiante tanto na educação como na literatura, principalmente naquilo que concerne às suas instituições.

$\mathrm{Na}$ esteira desses anseios criaram-se narrativas mestras. Uma destas passou a funcionar como uma das premissas da ciência clássica. Refiro-me ao dualismo cartesiano e à pressuposição de que "existe uma distinção fundamental entre a natureza e os seres humanos, entre a matéria e a mente, entre o mundo físico e o mundo social/espiritual" (WALLERSTEIN, 1996, p. 15). Esta premissa teve muitos desdobramentos e legou a ideia de que ao falar em ciência se está falando em ciência da natureza.

Thomas Hooke, ao redigir os estatutos da Royal Society, em 1663, assentia que o objetivo da ciência clássica seria o de aumentar o conhecimento das coisas naturais, e a elas estariam associadas "todas as Artes úteis, Manufaturas, práticas Mecânicas, Máquinas e Invenções pela via da Experimentação, desde que nesta não entrasse o Divino, a Metafísica, a Política, a Gramática, a Retórica, ou a Lógica" (WALLERSTEIN, 1996, p. 15). Seguindo a explicitação de Wallerstein (1996) já há nestes estatutos uma tradução que atua na divisão entre os modos de conhecimento que Charles Snow (1995) tratou pela designação de "As Duas Culturas", referindo-se à divisão entre Ciências Naturais e Humanidades.

Precisamos levar em consideração que, entre os séculos XVII e XVIII, aqueles que tentaram estabelecer a legitimidade e a prioridade da demanda científica das leis da natureza quase não fizeram distinção entre ciência e filosofia, consideravam que fossem domínios aliados. No entanto, no início do século XIX, à medida que o trabalho experimental e empírico se tornava cada vez mais crucial para a visão da ciência, a filosofia surgia como mera substituta da teologia, igualmente culpada de asserções de verdade apriorística não passíveis de serem postas à prova. Quando essa separação de mundos não ocorria, no sentido de descartar a noção de se tratar de esferas separadas se assumia, nesse descarte, uma hierarquia: o conhecimento tido como certo (ciência), por oposição ao conhecimento imaginado e mesmo imaginário (a não ciência). Essa hierarquia criou um triunfo linguístico para a ciência e fez marcar uma distinção onde a palavra ciência passou a designar, quase que exclusivamente, as ciências da natureza, procurando, com isso, "legitimar a ideia de que se trata de uma forma de conhecimento distinta de outra chamada de filosofia ou humanidades" (WALLERSTEIN, 1996, p. 18, grifo nosso).

Para dar ênfase nesse sentido cito diretamente uma afirmação do relatório da Comissão Gulbenkian para a reestruturação das Ciências Sociais, comissão esta criada em 1993 e coordenada por Immanuel Wallerstein (1996, p.19):

Revista Digital do LAV - Santa Maria - vol. 9, n. 2, p. 133 - 145. - mai./ago. 2016 ISSN 1983 - 7348 http://dx.doi.org/10.5902/1983734823517 
A ciência, ou seja, a ciência da natureza, foi objeto de uma definição mais clara do que o seu contraponto, para o qual o mundo não chegou nunca sequer a acordar num nome único. Umas vezes designada por artes, outras vezes chamada humanidades, outras ainda letras ou belle-lettres, e ainda de outras vezes apelidada de filosofia, simplesmente "cultura" ou, como sucede em alemão, Geisteswissenschaften, a alternativa à "ciência" foi assumindo uma face e uma ênfase variáveis, uma falta de coesão interna que não foi de molde a ajudar os respectivos praticantes a defender a sua causa junto das autoridades, principalmente se se considerar a sua aparente incapacidade de oferecer resultados "práticos". Com efeito, começara a tornar-se evidente que a luta epistemológica por aquilo que se considerava ser conhecimento legítimo já não era uma luta para saber quem havia de controlar o conhecimento relativo à natureza (já que os cientistas naturais haviam claramente adquirido direito exclusivos sobre este domínio por volta do século XVIII), mas antes uma luta em torno de quem havia de controlar o conhecimento relativo ao mundo humano.

Esse mundo humano e o homem como seu principal protagonista, ou melhor, essa ideia de homem como hoje a conhecemos, ganhou forma e valor a partir do século XVI, ou seja, sua existência é um acontecimento recente. Essa afirmação pode ser lida em As palavras e as coisas (1995), livro que Michel Foucault publica em 1966 e que afirma ter nascido de uma provocação borgeana. Lemos nas ultimas frases do livro,

O homem é uma invenção cuja recente data a arqueologia de nosso pensamento mostra facilmente. E talvez o fim próximo. Se estas disposições viessem a desaparecer tal como apareceram, se por algum acontecimento de que podemos quando muito pressentir a possibilidade, mas de que no momento não conhecemos ainda nem a forma nem a promessa, se desvanecessem, como aconteceu, na curva do século XVIII, com o solo do pensamento clássico - então se pode apostar que o homem se desvaneceria, como, na orla do mar, um rosto de areia (FOUCAULT, 1995, p. 404).

Nietzsche, de outro modo, já nos havia dado a ler que o conhecimento, essa invenção dos homens foi, talvez, apenas um minuto soberbo e mentiroso da história universal (1978, p. 45). O que Nietzsche e Foucault frisaram com destaque foi a condição fabulatória do eu-humano, do mundo humano reforçado pelas ideias iluministas, e que ganhou contornos metodológicos com Descartes. $\mathrm{E}$ mesmo Descartes não deixou de afirmar na primeira parte de seu Discurso do Método: para bem conduzir a própria razão e procurar a verdade nas ciências, o caráter fabuloso de seu texto:

[...] o meu intuito não é ensinar aqui o método que cada um deve seguir para bem conduzir a sua razão, mas apenas fazer ver de que maneira tratei de conduzir a minha. Os que se abalançam a dar preceitos devem se considerar mais hábeis do que aqueles a quem os dão; e se falham na menor coisa, são por isso censuráveis. Mas, não propondo este escrito senão como uma história, ou se preferirem, como uma fábula na qual, entre alguns exemplos dignos de ser imitados, se encontrarão também talvez vários outros que se terá razão em não seguir, espero que ele será útil para alguns, sem ser nocivo para ninguém, e que todos apreciarão minha franqueza (DESCARTES, 1955, p. 67).

\section{Um leitor}

Revista Digital do LAV - Santa Maria - vol. 9, n. 2, p. 133 - 145. - mai./ago. 2016 ISSN 1983 - 7348 http://dx.doi.org/10.5902/1983734823517 
Jorge Francisco Isidoro Luis Borges, um homem nascido ainda no século XIX, em 1899, como fosse o efeito de um jogo de espelhos surgido na biblioteca de la casa de la calle Tucuman, entre Esmeralda y Suipacha, nunca foi inocente a esse respeito. A precoce e estreita amizade com os livros fez de Borges um sabedor do teor fabulatório das ciências e suas conjecturas, do homem como invenção, assim como da relação que o saber trava com a realidade em um âmbito de empirismo imaginativo e imaginário.

Este leitor precoce aos sete anos escreve um conto intitulado La visera fatal, influenciado pela leitura que fez de Cervantes. Este conto consta em sua biografia de escritor, mas não se sabe se alguém o leu, ou se existe para além do título. Neste mesmo ano, em 1906, escreve, em inglês, o resumo da mitologia grega (Borges foi alfabetizado em inglês). Poucos anos mais tarde, em 1910, quando já tinha dez anos, publicou uma tradução de Oscar Wilde El príncipe feliz no jornal El País. Muitos atribuíram essa tradução a seu pai Jorge Guillermo Borges. Mas, de que Borges estamos falando? Neste momento: de Georgie, como era chamado em casa e pelos amigos próximos, do jovem Jorge Luis já capturado pelo universo das bibliotecas. Tão afeito a esse universo que mais tarde, em uma entrevista, diz que chega a confundir o rosto de seu pai com a imagem da biblioteca. O Borges de que falamos foi, sempre, um leitor.

No Prólogo da primeira edição de Historia Universal de la infamia de 1935 podemos ler: "A veces creo que los buenos lectores son cisnes aún más tenebrosos y singulares que los buenos autores". E acrescenta ao final "Leer, por lo pronto, es una actividad posterior a la de escribir: más resignada, más civil, más intelectual" (1974, p. 289). Borges vai fazer do ato de ler seu procedimento inventivo e poético onde os seus escritos se conformam em uma poética da leitura, como chamou Emir Rodrigues Monegal (1980). Trata-se de uma escritura que faz da mise en abyme um recurso, uma "perspectiva infinita de textos que remetem a textos que remetem a textos" (MONEGAL, 1980, p. 42). É nessa perspectiva labiríntica e vertiginosa que Borges faz de seu universo leitor uma relação disposta à escritura. Escrever seria uma empresa literária

que se baseia na "total" destruição da literatura e que, por sua vez, paradoxalmente, instaura uma nova literatura; uma écriture que se volta para si mesma para recriar, com suas próprias cinzas, uma nova maneira de escrever; uma fênix, oh, não muito freqüente (MONEGAL, 1980, p. 44).

Desse modo, falar Borges, parece-me que seria o mesmo que evocar, por um efeito metonímico, a imagem de uma biblioteca. Borges lia de tudo, mas ele mesmo afirmava não ter paciência para os romances e que nem sempre lia tudo por completo, livros inteiros, por assim dizer. O que importa neste universo de leitor é a potencialidade leitora, ou seja, as ínfimas relações que podem ser provocadas em leituras cruzadas. Como se as frases de um texto fossem concatenadas por um bibliotecário que, a cada ordenar e reordenar de uma biblioteca, vai inventariando frases, palavras, parágrafos de livros dispersos e, nessa ordem, faz dos fragmentos uma unidade discreta de sentidos. Entre os muitos escritores conhecidos e desconhecidos, inventados e reais desse universo borgeano, gostaria de ressaltar um nome recorrente nessa biblioteca-Borges. Esse nome é Paul Valéry e, evidentemente, o lastro das leituras valéryanas que adentram o universo borgeano. Edgar Allan Poe, 
Nietzsche, Descartes, Marcel Scwoob, Spinoza são alguns exemplos. Borges foi um leitor tão ativo de Paul Valéry que Ítalo Calvino chega a afirmar que

se tivesse de apontar quem na literatura realizou perfeitamente 0 ideal estético de Valéry da exatidão de imaginação e de linguagem, construindo obras que correspondem à rigorosa geometria do cristal e à abstração de um raciocínio dedutivo, diria sem hesitar Jorge Luis Borges (CALVINO, 2000, p.133).

Se passássemos a desenhar uma teia de relações no âmbito das probabilidades entre Paul Valéry (1871-1945) e Jorge Luis Borges (1899-1986), essa teia nos levaria, talvez, a um mundo de rigorosa ordem transversal entre poesia, ciência, filosofia e artes, fora outras misteriosas curiosidades inventivas. Como se pudéssemos ler, anacronicamente, Edgar Allan Poe como um leitor de Borges e Valéry a escrever um conto de enigma e mistério que se passa na cidadezinha de Fray Bentos, no Uruguay. Nesse conto Funes e Monsieur Teste se sentam frente a frente, ou, lado a lado, con un mate e croissants. E então, no silêncio desse encontro, ecoaria um murmúrio de vozes valeryanas e borgeanas. Teríamos aí a conexão entre dois personagens silenciosos da literatura universal, Funes o monstro da memória, o Zaratustra xucro (personagem de Borges) e Monsieur Teste o monstro da lucidez e do rigor, aquele que diz: A tolice não é o meu forte! (personagem de Valéry). Mas talvez, o resultado dessa teia seria, somente, o efeito da literatura a recriar suas próprias cinzas.

Em Ficciones há um conto em que essa relação entre Valéry e Borges aparece de forma mais explicita. Refiro-me ao Pierre Menard, el autor del Quijote. Leio nele a fórmula valéryana da comédia intelectual tomada por um procedimento borgeano: o do comentário, da resenha do livro e do autor hipotético. Ambos me dão matéria de conformação a um fazer didático que chamo de didática da leitura, que atua de forma anacrônica e se estabelece por meio de uma comédia intelectual na Educação. Essa comédia se conformaria com o gesto, sempre inconcluso, de pensar o pensamento das intelectualidades que ofertaram ao mundo suas criações. E, por meio desse pensar, disposto ao âmbito da impossibilidade, recriar os seus possíveis.

O que podemos frisar destas leituras são, justamente, os modos de ler. Monsieur Teste (o conjunto de textos que compõe o livro que Valéry publica em 1895) resulta das leituras que este faz, dentre outros, de Descartes. Valéry parece seguir à risca a advertência que Descartes faz no início de seu Discurso, e afirma ter lido o Discurso do Método, como fosse um romance.

A aposta está na afirmação de que os modos de ler carregam de perspectivismo autoral todo e qualquer texto, fazendo com que ciência, filosofia e arte se cruzem em uma inseparável relação disposta ao conhecimento, ou seja, disposta às potências de transformação de nós mesmos e da vida. Esse parece ter sido o legado desses leitores.

A perturbação de Foucault está justamente, como leitor de Borges, no modo como seus textos apontam para os limites de nosso pensamento e a possibilidade patente de se pensar esses limites. A questão de Borges, como dissemos, foi desde sempre uma questão de leitura, em que os modos de ler se tornam uma temática em seus textos. Poderíamos dizer que, seguindo o legado borgeano, ao ter contato com um tema, o que importa não é seu conteúdo, mas o modo como o leio. Aliás, talvez seja justamente o modo de ler que faz da leitura matéria de escrita; seria ela mesma continente 
e conteúdo de um multiverso travado pelo leitor. Talvez seja por isso que Borges, ao falar para uma plateia, considera que, como afirmou na primeira das sete palestras ministradas no Teatro Coliseu de Buenos Aires, em 1977, não se dirige a todos de uma só vez, mas a cada um em particular. Em um texto publicado na Revista Sur em 1951, intitulado Notas sobre (hacia)Bernard Shaw, incluído na coletânea Otras inquisiciones, lemos:

[...] um livro é mais que uma estrutura verbal, ou que uma série de estruturas verbais; é um diálogo que trava com seu leitor e a entonação que impõe à voz dele e as imagens cambiantes e duráveis que deixa em sua memória. Esse diálogo é infinito [...]. Uma literatura difere de outra, ulterior ou anterior, menos pelo texto do que pela maneira de ser lida: se me fosse outorgado ler qualquer página atual - esta, por exemplo - como a lerão no ano 2000, eu saberia como será a literatura do ano 2000 (BORGES, 2007, p.182-183).

Borges, desafeito aos gêneros literários, acaba por inventar um. Inventar, aliás, a si próprio como narrador. "A ideia de Borges foi fingir que o livro que desejava escrever já havia sido escrito por um outro, um hipotético autor desconhecido, que escrevia em outra língua e pertencia a outra cultura - e assim comentar, resumir, resenhar esse livro hipotético" (CALVINO, 2000, p.63). O que Borges faz, ao escrever, é narrar de uma maneira sintética e abreviada o seu modo de ler.

No prólogo de Ficciones (primeira parte, 1941), Borges justifica seu gosto pelos textos curtos: "Desvario trabalhoso e empobrecedor o de compor vastos livros; o de espraiar em quinhentas páginas uma ideia cuja perfeita exposição oral cabe em poucos minutos. Melhor procedimento é simular que esses livros já existem e propor um resumo, um comentário" (2005). O que temos é um conjunto de narrativas que colocam em suspensão as noções comuns que até então se tinha dos gêneros literários. Borges trava, com seus textos, um modo de desarticular as expectativas do leitor com relação ao que se pode esperar de um conto. A primeira vez que li Borges, ou melhor, o primeiro texto que li com sua assinatura, foi Tlön, uqbar, orbis tertius. Como um estudante de Ciências Sociais, que se dava uma trégua das leituras epistemológicas de Karl Popper e Thomas Kuhn para ler algo de literatura, senti certo mal estar. Minha postura de leitor, isto é, meu modo de ler havia configurado, mais ou menos, o que eu encontraria num conto. Mas, naquele momento, eu não reconhecia o que lia como um conto e me perguntava, indo e voltando nas páginas, mas onde está o conto? Quando começa o conto? Parecia-me estar lendo apenas um comentário de Borges que citava seu amigo e escritor Adolfo Bioy Casares; o comentário versava sobre espelhos, sobre um artigo que constava em uma enciclopédia. Mas o texto seguia e eu me dizia, espantado e sem conseguir parar a leitura, onde está o conto? Sentia-me lendo comentários sobre uma enciclopédia ausente, ou sobre um tema: Uqbar que haveria de ser lido nessa enciclopédia. Porém, ao mesmo tempo, tinha a impressão de estar lendo um texto de razão epistêmica. De fato, o que minha ingênua atitude de leitor, cheia de certezas, havia encontrado era o que hoje estou chamando de aporias literárias.

Nessa inventiva, a literatura de Borges nos lega a ideia (a nós professores e pesquisadores na área da Educação), de que é necessário, para manter estes fazeres (o da Educação e também o literário cumprindo certa função, o que não se confunde com funcionalismos), empreender projetos que outros ainda não tentaram imaginar e que nós mesmos não saberíamos dizer para onde nos levarão. Mas os empreendemos como um modo de praticar certo desvio das metarrativas fundacionais como 
prescritivas de nossas práticas ou, ainda, para encontrar maneiras de desestabilizar os poderes, as certezas e os dogmas. E é por isso que importa fazer alianças variadas, como as que encontramos nas leituras dos textos borgeanos e outros tantos.

\section{Aporias literárias}

O universo borgeano é vasto como o de uma biblioteca. No entanto, poderíamos abordá-lo a partir de um conto somente. Como aquele que fez Foucault escrever um livro de quatrocentas páginas, a saber: "O idioma analítico de John Wilkins". Para este texto escolhi três pontos desdobrados em temáticas que me parecem interessantes ser tratadas na Educação. Claro que o que faremos aqui são apenas sinalizações: 1) A invenção de Borges (a subjetivação como um efeito de variação); 2) O conhecimento como fabulação (a erosão da verdade como essência) e 3) O anacronismo como procedimento didático (uma didática dos modos de ler).

\section{1) A invenção de Borges (a subjetivação como um efeito em variação)}

Em 1977, Roger Caillois, um dos fundadores do Collège de Sociologie, fez uma entrevista com Borges no centro Pompidou, em Paris. A entrevista, publicada mais tarde (no ano de 1987) em espanhol numa revista editada em Montevidéu e de nome Vuelta Sudamericana, recebeu o título de Dialogo fugaz. A entrevista começa assim:

[R.C.] - E então, meu querido Borges, há quase trinta anos nos conhecemos. Desde então tenho notado que...

[J.L.B.] - Sim, naquele tempo você me inventou.

[R.C.] - Não, não.

[J.L.B.] - Então me inventou um pouco depois... (CAILLOIS; BORGES, 1987, grifo nosso).

Precisamos contextualizar esse diálogo, pois ele se configura como um agregado de circunstâncias que podemos utilizar para imaginar um Borges invenção. Em 1939 Victória Ocampo, a editora da Revista Sur, irmã de Silvina Ocampo, esposa de Adolfo Bioy Casares, convidou Roger Caillois para ir a Buenos Aires. Caillois passa todo o período da Segunda Grande Guerra em Buenos Aires, morando na casa de Victoria Ocampo. As casas de Victoria, tanto em Buenos Aires como em Paris, foram sempre lugares de encontros entre escritores e intelectuais. Em 1945, com o fim da Guerra, Roger Caillois volta a Paris e lança uma coleção chamada La croix du Sud, pela editora Gallimard. Essa coleção é especializada em literatura sul-americana. Assim, Borges começa a ser traduzido e publicado em francês e, logicamente, começa a ser conhecido e reconhecido para além do mundo de fala hispana. Foi por meio destas traduções que ele foi lido por Foucault, Deleuze, Blanchot, Gerard Genette. Todos esses citam Borges em suas obras. A literatura de Borges também influenciou a Literatura Potencial do OuLiPo, grupo de escritores fundado por Raymond Queneau e Françoise Le Lyonnais; fazem parte deste Grupo: Calvino e George Perec, dois escritores que citam e se valem muito da literatura borgeana. Para dar ênfase a este momento em que a literatura de Borges começa

Revista Digital do LAV - Santa Maria - vol. 9, n. 2, p. 133 - 145. - mai./ago. 2016 ISSN 1983 - 7348 http://dx.doi.org/10.5902/1983734823517 
a ser conhecida, em 1961 foi premiado, junto com Samuel Beckett, com Prêmio Formentor de literatura.

Temos aí os momentos da invenção de Borges, que este atribui a Caillois. Claro que isso começou muito antes, talvez já naquelas linhas de La visera fatal ou, antes ainda, frente aos livros da biblioteca de seu pai.

O que nos interessa é o fato de Borges sempre ter deixado claro sua relação entre o Borges da casa, o da pessoalidade (Georgie), e Jorge Luis Borges, o escritor. No epílogo de El hacedor [O fazedor], livro publicado em 1960 e que reuniu uma miscelânea de textos seus escritos de ocasiões e temas diversos, podemos ler:

Um homem se propõe a tarefa de desenhar o mundo. Ao longo dos anos, povoa um espaço com imagens de províncias, de reinos, de montanhas, de baías, de naus, de ilhas, de peixes, de moradas, de instrumentos, de astros, de cavalos e de pessoas. Pouco antes de morrer, descobre que esse paciente labirinto de linhas traça a imagem de seu rosto (BORGES, 2008, p.168).

Esse trecho pode ser lido como um espelhamento tradutório da frase valéryana do texto "Poesia e pensamento abstrato" que diz: "Na verdade, não existe teoria que não seja um fragmento cuidadosamente preparado de alguma autobiografia" (VALÉRY, 1991, p. 204). Trata-se de ver, sempre, que a vida está implicada na obra; vida e obra se retroalimentam. Nesse mesmo volume podemos ler o texto "Borges e eu"

Ao outro, a Borges, é que acontecem as coisas. Eu caminho por Buenos Aires e demoro-me, talvez já mecanicamente, na contemplação do arco de um saguão e da cancela; de Borges tenho notícias pelo correio e vejo o seu nome num trio de professores ou num dicionário biográfico. Agradam-me os relógios de areia, os mapas, a tipografia do século XVIII, as etimologias, o sabor do café e a prosa de Stevenson; o outro comunga dessas preferências, mas de um modo vaidoso que as converte em atributos de um actor. Seria exagerado afirmar que a nossa relação é hostil; eu vivo, eu deixo-me viver, para que Borges possa urdir a sua literatura, e essa literatura justifica-me. Não me custa confessar que conseguiu certas páginas válidas, mas essas páginas não me podem salvar, talvez porque 0 bom já não seja de alguém, nem sequer do outro, mas da linguagem ou da tradição. Quanto ao mais, estou destinado a perder-me definitivamente, e só algum instante de mim poderá sobreviver no outro. Pouco a pouco vou-lhe cedendo tudo, ainda que me conste o seu perverso hábito de falsificar e magnificar. Espinosa entendeu que todas as coisas querem perseverar no seu ser; a pedra eternamente quer ser pedra, e o tigre um tigre. Eu hei-de ficar em Borges, não em mim (se é que sou alguém), mas reconheço-me menos nos seus livros do que em muitos outros ou no laborioso toque de uma viola. Há anos tratei de me livrar dele e passei das mitologias do arrabalde aos jogos com o tempo e com o infinito, mas esses jogos agora são de Borges e terei de imaginar outras coisas. Assim, a minha vida é uma fuga e tudo perco, tudo é do esquecimento ou do outro. Não sei qual dos dois escreve esta página (BORGES, 2008, p.54).

Temos aqui uma lição para a Educação que nos diz que o eu não é unificado. Que esse eu que conhecemos se substancializa com a gramática e se trata de um efeito da linguagem. $O$ eu se 
configura, assim, como uma variação e um modo de dizer. Não se trata, então, de evocar um eu centralizado, um núcleo sólido de um sujeito com saberes vindo de alhures e acumulados em um ser. Diferentemente, aquele passa a ser os fazeres de uma singularidade ilustrada por um mito que a suporta, os modos de subjetivação. Esse eu se desvanecerá como lágrimas na chuva (para evocar a fala do replicante interpretado por Rutger Hauer no filme "Blade Runner, o caçador de androides") ou na orla do mar, como um rosto na areia (repetindo Foucault).

Uma identidade docente correlata com a noção de que o eu não passa de um efeito da linguagem, da gramática, do texto, da enunciação, privilegia as conexões e as superfícies de contato. As leituras, mesmo quando rápidas e breves, podem potencializar-se como densas e fortes. Não se trataria mais de procurar ler as essências das coisas, encontrar seus núcleos sólidos, suas consciências; assim fazendo, não se sairia do âmbito da representação, ato que decalca e interrompe os fluxos. Nestas leituras potencializadas, a ideia de compreensão dá passagem para a de tradução. Escrever é traduzir, nos diz Valéry (1956); aprender a falar é traduzir, nos diz Octávio Paz (2009). E traduzir seria, sempre, recriar um estado de espírito, uma paideuma. A tradução, como nos mostra Octavio Paz (e Borges é considerado um teórico da tradução), não é uma operação com tendência a mostrar a identidade última dos homens, mas um veículo de suas singularidades. As superfícies de seus fazeres; aí estaria o Ethos docente.

\title{
2) $O$ conhecimento como fabulação (a erosão da verdade como essência)
}

Na mesma entrevista que citamos acima, diz Borges: "- creio que a Ética de Spinoza é a obra mestra da literatura fantástica. Mas também a Suma teológica, de São Tomás" (CAILLOIS; BORGES, 1987). Borges nunca lê verdades, seja a forma de pensamento que for, ele lê literatura, ele faz, daquilo que lê, literatura. Seu modo de ler nos diz que, o conhecimento é um campo de invenção, como uma afecção ativa. Evocamos aqui outro texto de Borges publicado na coletânea intitulada El hacedor [O fazedor]:

\begin{abstract}
Do rigor da ciência
... Naquele Império, a Arte da Cartografia logrou tal perfeição que o mapa de uma única Província ocupava toda uma Cidade, e o mapa do império, toda uma Província. Com o tempo, esses Mapas Desmedidos não satisfizeram e os Colégios de Cartógrafos levantaram um Mapa do Império, que tinha o tamanho do Império e coincidia pontualmente com ele. Menos Adictas ao Estudo da Cartografia, as Gerações Seguintes entenderam que esse dilatado Mapa era Inútil e não sem Impiedade o entregaram às Inclemências do Sol e dos Invernos. Nos desertos do Oeste perduram despedaçadas Ruínas do Mapa, habitadas por Animais e por Mendigos; em todo o País não há outra relíquia das Disciplinas Cartográficas.

Suáres Miranda: Viajes de Varones Prudentes, livro quatro, cap. XLV, Lérida, 1658 (BORGES, 2008, p.155).
\end{abstract}

A ciência aparece como essa dilatada fantasmagoria, que procura ser uma cópia perfeita e ampliada daquilo que se presta a conhecer.

No texto "O idioma analítico de John Wilkins", que deixou Foucault perplexo, lemos: "A impossibilidade de penetrar no esquema divino do universo não pode, contudo, dissuadir-nos de planejar esquemas humanos, embora nos conste que estes são provisórios" (BORGES, 2007, p.125).

Revista Digital do LAV - Santa Maria - vol. 9, n. 2, p. 133 - 145. - mai./ago. 2016 ISSN 1983 - 7348 http://dx.doi.org/10.5902/1983734823517 
Há, na literatura borgeana, uma fortuna pedagógica. Uma pedagogia que nos conduz ao arbitrário e provocativo universo das bibliotecas. Ao entrar nessa biblioteca, somos exortados a uma prática de ensino; trata-se de uma autocriação formativa que passa da Bildung (formação) à Erlebnis (experimentação). Pois automaticamente nos tornamos escritores do que estamos lendo, e quando nos damos conta dessa razão inversa e complementar - a da leitura que se torna escritura e a escritura que se torna leitura - passamos a ler e escrever de outro modo (e nesse mesmo sentido podemos entender o que nos diz Piglia (1996) a respeito da crítica). Ao tornar-nos escritores do que lemos e escrevemos não buscamos mais ler tudo, saber tudo, mas nos dispomos a armar uma rede com a qual vamos construindo e situando a nós mesmos como uma ficção que se coloca em certo campo de atuação. Passamos a ler e escrever, é claro, desse lugar. Estabelecendo cortes, conexões, contágios, relações de lutas e tensões em que não há mais, ou é justamente aqui que ela falha, a ideia de que um professor pode fazer o seu métier afastado da pesquisa, afastado de uma reflexão e à margem daquilo que faz. Pois este seria um professor ingênuo, levado a seguir verdades, sejam elas teóricas, filosóficas, artísticas ou pessoais. Esse professor das verdades constituiria o mito do professor espontâneo, aquele que professa uma lei, que emana uma voz interior. Nada disso! Se, como nos diz Piglia, a verdadeira experiência do escritor é a escritura, por ser uma experiência intensa que faz com que se conheça todo um jogo de impessoalidades que essa singularidade de escritor provoca, a verdadeira experiência do docente está aí irmanada, pois seu fazer não pode confundir-se com "dar uma aula", passar conteúdos, transmitir saberes. A experiência docente se configura quando ele deixa de repetir fórmulas do mesmo e passa a traduzir. Desde que nessa tradução haja reflexão a respeito daquilo que faz e, também, principalmente, daquilo que deixa de fazer por ter decidido não fazê-lo.

\title{
3) $O$ anacronismo como procedimento didático (uma didática dos modos de ler)
}

No conto, talvez o mais conhecido de Ficciones, "Pierre Menard, el autor del Quijote" - que é citado por Gerard Genette em Figuras para afirmar que a obra de Borges parece ser possuída por um estranho demônio da associação -, podemos ler a respeito do procedimento menardiano de leitura. Procedimento esse que faz com que Menard possa ser autor do Quixote, pelo menos dos capítulos IX e XXXVIII da primeira parte e de um fragmento do capítulo XXII. Lemos, já no final do conto:

\begin{abstract}
Pensar, analisar, inventar [...] não são atos anômalos, são a respiração normal da inteligência. Glorificar o ocasional cumprimento dessa função, entesourar antigos e alheios pensamentos, recordar com incrédula estupefação o que o doctor universalis pensou, é confessar nossa languidez ou nossa barbárie. Todo homem deve ser capaz de todas as ideias e entendo que no futuro será.

Menard (talvez sem querer) enriqueceu mediante uma técnica nova a arte detida e rudimentar da leitura: a técnica do anacronismo deliberado e das atribuições errôneas. Essa técnica de aplicação infinita nos insta a percorrer a Odisséia como se fosse posterior à Eneida e o livro [...] Essa técnica povoa de aventura os livros mais pacatos [...] (BORGES, 2005, p.44-45).
\end{abstract}

O que está em jogo nessa técnica menardiana é novamente o ato de ler. Gerard Genette afirma que o que ela instaura é um "espaço homogêneo e reversível onde as particularidades individuais e as

Revista Digital do LAV - Santa Maria - vol. 9, n. 2, p. 133 - 145. - mai./ago. 2016 ISSN 1983 - 7348 http://dx.doi.org/10.5902/1983734823517 
precedências cronológicas não tem valor" (GENETTE apud MONEGAL, 1980, p.26). Essa mesma ideia pode ser lida, dentre outras, no conto "Kafka y sus precursores" (BORGES, 2007), em que o texto conclui que cada escritor, leia-se também leitor, cria seus precursores.

Tomado por essas atribuições literárias sobre a leitura, essa noção de anacronismo me acompanha como um método. A noção nos permite idear a pesquisa e a docência como se fosse tomada por sínteses disjuntivas. Aquelas que se ativam como conectores de neutralidade que separam e desligam, incorporam, virtualizam e juntam (BADIOU, 2000). Trata-se, de um poder que nos permite afirmar o que é díspar e provocar encontros impossíveis em ordens lineares. Com o anacronismo praticado nos modos de ler, técnica menardiana, posso inferir paradoxos ao borrar as distâncias entre passado, presente e futuro. O que faço, quando me imponho o anacronismo, é moldar o tempo em uma leitura que se faz escrita. Nesse ato, tomo para mim, como leitor que escreve, um poder com o tempo de uma dicção alheia, a retenho na memória que se molda no processo à escritura, faço tradução. O que leio e escrevo, fazendo dessa escrita uma didática, já não é o lido, nem algo sobre a leitura, pois o próprio fazer tomou um poder de movimentar-se para além do tempo. No espaço de uma aula, como no de uma folha, podem ser atribuídos outros lugares e outros registros. Nessa interferência os encontros são inusitados. Matérias de tempos e espaços alhures se conectam. Falo de educação com um filme, um conto, um tweet... Trata-se de incorporar a frase de Boileau que impressionava Borges: "O momento em que falo já está longe de mim" (CAILLOIS; BORGES, 1987).

\section{Borges e a Educação}

Gostaria de afirmar que me interessa tratar a educação com temas e procedimentos literários do tipo borgeano. Primeiramente, por entender que sua literatura não é leitura para ser compreendida no correr da linha, mas para ser sentida. Precisamos sentir seus efeitos. Dotar de inventividade enciclopédica nosso próprio eu-leitor. Em seguida, porque essas leituras nos colocam num âmbito incerto; diluem-se as fronteiras, suspendem-se os códigos de leitura, os gêneros, as hierarquias e cronologias. Precisamos, no ato de ler, criar nosso próprio modo de ler, criar nossos precursores. Mais ou menos nesse sentido nos diz Borges: "tenho tentado, não sei com que sorte, a redação de contos diretos. Não me atrevo a afirmar que são simples; não há na terra uma só página, uma só palavra, que o seja, já que todas postulam o universo, cujo mais notório atributo é a complexidade" (BORGES, 1974, p. 1021, tradução nossa).

Ao sermos leitores assíduos de seus textos, parece que somos convidados a afinar uma escuta que possa, por detrás de uma multiplicidade de temas, perceber certa repercussão de estilos de pensamento. O de Borges, sem dúvida, é o de sugerir a ambiguidade do pensar. Essa ambiguidade não se apresenta sem a oferta para conjecturar, para criar, inclusive, linhas da tradição. Não digo somente criar com essas linhas, mas, principalmente, criar as próprias linhas. Suportar, por exemplo, um excesso de coerência racional, como a do estilo spinoziano de pensamento, sem deixar de evocar o fantástico e o heteróclito; fazer ruir a sintaxe das ordens utópicas com o diapasão dessas mesmas ordens; trapacear a língua, talvez nos dissesse Roland Barthes. É disso que se trata: usar as linguagens para travar diálogos e o livro é, ele mesmo, um diálogo, uma forma de relação, nos diz

Revista Digital do LAV - Santa Maria - vol. 9, n. 2, p. 133 - 145. - mai./ago. 2016 ISSN 1983 - 7348 http://dx.doi.org/10.5902/1983734823517 
Borges. Em um diálogo o interlocutor não é a soma ou a média daquilo que diz, mas todos os microefeitos que transluz sua expressão.

Para finalizar esta fala/texto, que incorpora relações entre Literatura e Educação, esse encontro que considero inexpugnável, tomo de empréstimo uma anedota contada por Liz Themerson no prólogo do livro Perder Teorias, de Enrique Vila-Matas (2010). Escritor catalão que incorpora, em muitas circunstâncias, o estilo borgeano de fazer literatura.

Themerson conta que, quando estourou a guerra civil espanhola, o escritor Pío Baroja foi caminhando até a fronteira com a França que ficava ao lado de sua casa.

Então ele perguntou aos policiais da aduana: -¿Se puede pasar? Pase usted, don Pío, pase. Responderam eles. E foi assim, nessa passagem aparentemente suave e fácil, que Pío Baroja mudou-se de país e se exilou na França. Mas, sabemos que para cometer uma travessia como essa, a que comporta um exílio, é necessário que estejamos prontos para perder muitas coisas. Para passar certa fronteira e começar a habitar uma Educação que experimenta e cria é necessário estar disposto a perder certezas, estabilidades, razões hierarquicas utilitaristas, autoridade arbitrária e inútil e, nessa perda, ganhar ou reinventar a capacidade de estranhar, a capacidade de ler (ao ter perdido o modo harmônico de fazer uma leitura) a capacidade de naufragar como fez o Robinson de Michel Tournier que, depois do naufrágio e da redescoberta da terra, pelo encontro que teve com Sexta-feira (o araucano), deu outro valor ao governo da terra, do medo, dos outros e de si.

\section{Referências}

BADIOU, Alain. Da vida como nome do ser. In. ALLIEZ, Éric. Gilles Deleuze: uma vida filosófica. (Coord. De trad. Ana Lúcia de Oliveira). São Paulo: Ed. 34, 2000, p. 159-167.

BORGES, Jorge Luis. O fazedor (Trad. Josely Vianna Baptista). São Paulo: Companhia das Letras, 2008.

BORGES, Jorge Luis. Outras inquisições. (Trad. Davi Arriguchi Jr.). São Paulo: Companhia das Letras, 2007.

BORGES, Jorge Luis. Ficções (Trad. Davi Arriguchi Jr.). São Paulo: Companhia das Letras, 2005.

BORGES, Jorge Luis. Obras completas 1923-1972. Buenos Aires: Emecé Editores, 1974.

CALVINO, Ítalo. Seis propostas para o próximo milênio (Trad. Ivo Barroso). São Paulo: Companhia das letras, 2000.

CAILLOIS, Roger; BORGES, Jorge Luis. Diálogo fugaz. Vuelta Sudamericana. Montevideo. Maio, 1987.

DESCARTES, René. Discurso do Método. Para bem conduzir a própria razão e procurar a verdade nas ciências. (Tradução Maria de Lourdes Teixeira.) São Paulo: Martins Editora, 1955.

FOUCAULT, Michel. As palavras e as coisas (Trad. Salma Tannus Muchail). São Paulo: Martins Fontes, 1995.

MONEGAL, Emir Rodríguez. Borges: uma poética da leitura (Trad. Irlemar Chiampi). São Paulo: Perspectiva, 1980.

NIETZSCHE, Friedrich. Sobre verdade e mentira no sentido extra-moral (Trad. Rubens Rodrigues Torres Filho). In: Obras incompletas (Col. Os pensadores). São Paulo: Abril Cultural, 1978, p. 43-52.

Revista Digital do LAV - Santa Maria - vol. 9, n. 2, p. 133 - 145. - mai./ago. 2016 ISSN 1983 - 7348 http://dx.doi.org/10.5902/1983734823517 
PAZ, Octavio. Traducción: literatura y literalidade. Belo Horizonte: FALE/UFMG, 2009.

SNOW, Charles Percy. As Duas Culturas e uma segunda leitura: uma versão ampliada das Duas Culturas e Revoluções Científicas. Saço Paulo: EDUSP, 1995.

VALÉRY, Paul. Variedades. (Trad. João Alexandre Barbosa.) São Paulo: lluminuras, 1991.

VALÉRY, Paul. Variations sur les Bucoliques. Paris: Gallimard, 1956.

WALLERSTEIN, Immanuel et al. Para abrir as ciências sociais. São Paulo: Cortês, 1996.

i Professor Adjunto do Departamento de Ensino e Currículo da Faculdade de Educação da UFRGS. Pesquisador na Linha de Pesquisa Filosofias da Diferença e Educação PPGEDU/UFRGS.

Enviado em: 30 de maio de 2016.

Aprovado em: 01 de agosto de 2016. 